\title{
The Impact of Real Exchange Rate Depreciation on Cameroon's Trade Balance: Is Devaluation a Remedy for Persistent Trade Deficits?
}

\author{
Laetitia P. Sokeng Dongfack* \\ School of Economics, Huazhong University of Science and Technology \\ Hongbing Ouyang \\ School of Economics, Huazhong University of Science and Technology
}

\begin{abstract}
Time-series data from 1980 to 2016 were analyzed to estimate the impact of local currency (i.e., CFA Franc) devaluation on Cameroon's trade balance. The estimation of short-run and long-run relationships between the variables using Johansen cointegration and the vector error correction model (VECM) as a mean to examine whether the Marshall-Lerner condition (MLC) and the J-curve phenomenon hold in the case of Cameroon yielded mitigated results: Although the MLC is not met for Cameroon, as the sum of the elasticities of demand for exports and imports is not greater than unity, the empirical analysis results provide evidence of correction over the long-run of a prior deterioration of the trade balance at an adjustment speed of $81.17 \%$, thus supporting the existence of the J-curve pattern.
\end{abstract}

JEL Classification: F31, F41, E42

Keywords: Trade balance deficit, Real exchange rate, Marshall-Lerner condition, Devaluation, J-curve pattern.

\footnotetext{
* Corresponding author: Laetitia P. Sokeng Dongfack; PhD candidate in School of Economics, Huazhong University of Science and Technology, Luoyu Road 1037, Wuhan, China, 430074, Tel: 0086-27 87542457, Fax: 0086-27-87547833, E-mail: laetitia.sokeng@gmail.com

Co-Author: Hongbing Ouyang; Professor, School of Economics, Huazhong University of Science and Technology, Luoyu Road 1037, Wuhan, China, 430074, Tel: +8627 87542457, E-mail: ouyanghb@126.com
}

Acknowledgements: The author acknowledges funding from National Natural Science Foundation of China (Grant No. 71872067) 


\section{Introduction}

The persisting trade deficit in Cameroon can be explained, according to some economists, by its overrated local currency: the CFA Franc. Therefore, it slows down exports by hindering the competitiveness of Cameroonian goods on the international market, hence the need to consider its devaluation. This macroeconomic adjustment is based on the wellknown principle of the Marshall-Lerner condition (MLC), which says that if the summation of price elasticities of demand for exports and imports is greater than unity, the depreciation/ devaluation of a country's currency will lead to an improvement in the trade balance. Due to this assumption, considering the fact that a weakening of a country's currency will lead to an improvement in the trade balance actually depends on the responsiveness of consumers of imported goods within the said nation and consumers of that country's exports abroad. Moreover, there is an adjustment period where the devaluation will lead to deterioration before an improvement happens, following the J-curve pattern. However, if the sum of price elasticities of demand for exports and imports is less than unity, then a depreciation or devaluation of the currency will lead to worsening the trade balance.

The main concern of the member countries of the CFA zone, since the commodity and oil price shocks of the early 1970 s, is the difficulty to maintain adequate foreign reserves (with less than $20 \%$ coverage since 2008), necessary to sustain the value of their currency. Thus, they depend more on the stability given by the fixed exchange rate system of the CFA Franc (pegged on the French Franc). The devaluations - first in 1960, then in 1994as well as the implementation of the structural adjustment plan in the mid-1990s, led to an economic austerity climate from which Cameroon is struggling to escape. In the context where importation is a substitute for industrialization and where economic growth relies heavily on the exportation of unprocessed raw materials, for which prices are mostly decided in foreign financial markets, can the devaluation of the CFA Franc be a possible remedy to the persisting trade deficit in Cameroon?

Although many studies have investigated the effect of the depreciation or devaluation of a currency on its country's trade balance, research on the specific case of Cameroon is hardly common. And considering the fact that that country struggles to eradicate its trade deficit, the present research may be useful. Therefore, in order to fill the void, we will first attempt to define whether or not the MLC is met between Cameroon and its main trading partners. In the case where the MLC is satisfied, meaning the devaluation of the CFA Franc can reduce the trade deficit, we will conclude that this currency is indeed overrated for the Cameroonian economy. As member of the Coopération Financière d'Afrique (CFA), Cameroon cannot use the nominal exchange rate as a tool of macroeconomic adjustment. However, consider the fact that real exchange rate depreciation's effect on adjusting macroeconomics imbalances is a possible alternative demonstrated by Devarajan and Melo (1987). Accordingly, this paper analyzes the behavior of the trade balance with respect to real exchange rate depreciation, along with domestic and foreign income. It is structured as follows: Section 2 is a brief description and historical overview of the CFA Franc, followed by a literature review and study background in Section 3. Section 4 covers model specification, estimation 
techniques and econometric analysis, while empirical results and interpretation of findings will be discussed in Section 5 concerning the impact of changing the real exchange rate on Cameroon's trade balance in particular, in both the short and long runs. Finally, Section 6 serves to provide the conclusion and recommendations.

\section{Cameroon and the CFA Franc Exchange-Rate Regime}

Because of the weakness of the French Franc (FF) after World War II, the CFA Franc was created for French colonies in West and Central Africa on December 26, 1945. The CFA Franc originally stood for Franc des Colonies Françaises d'Afrique (African French Colonies Franc) but nowadays it bears two different meanings due to the fact that, two separates currencies were created for each of those regions: the West African CFA Franc (XOF) where CFA nowadays stands for Communauté Financière d'Afrique (African Financial Community) and the Central African CFA Franc that stands for Cooperation financière d'Afrique (African Financial Cooperation). Although these two currencies have the same exchange rate with the Euro and are both guaranteed by the French treasury, they cannot be interchanged: the CFA used in West Africa cannot be used in Central Africa. As part of Central Africa, Cameroon uses the Central African CFA Franc (XAF) as its local currency issued by the Bank of Central African States (BEAC), located in Yaoundé, the capital of Cameroon. Notably, the fixed parity with the FF has changed over the years, as seen in Table 1.

Table 1. The CFA Franc fixed parity with the French currency

\begin{tabular}{|c|c|c|}
\hline Date & CFA Franc (XAF) & French Franc (FF) / Euro \\
\hline $1945 \sim 1948$ & 1.00 & 1.70 \\
\hline $1948 \sim 1959$ & 1.00 & $2.00^{*}$ \\
\hline $1960 \sim 1994$ & 1.00 & $0.02^{* *}$ \\
\hline $1994 \sim 1998$ & 1.00 & 0.01 \\
\hline $1999 \sim 2019$ & 655.95 & $1.00^{* * *}$ \\
\hline
\end{tabular}

(Notes) (*) The French Franc was depreciated (**) Establishing the "new" French Franc, 1 "new" FF $=100$ "old" FF. (***) The CFA Franc is now pegged to the Euro.

(Source) Histoire du Franc CFA, found on the website of the BCEAO (Banque Centrale des États de l'Afrique de l'Ouest), last updated in 2018.

The argument behind the criticism of the so-called high value of the CFA Franc is the fact that the urban elite can afford imported goods at cheaper prices, while farmers in rural areas struggle to export agricultural products. The present study is an attempt to answer the question: is the real effective exchange rate's depreciation an effective tool in reducing these 
macroeconomic imbalances? From 1945 to 1959, the CFA Franc was stronger than the FF. But after the independence of many African countries in 1960, the decision was made by the French government to establish a new Franc to replace the old one (1 "new" FF $=100$ "old" FF). Even if technically the CFA Franc has not been devaluated, it became weaker against the former colonial power's currency, which happened to be the main trading partner of those newly independent countries. Actual devaluation of the CFA Franc happened in 1994, but in 2000, again, the FF disappeared and was replaced by the Euro, against which the value of the Cameroonian currency dropped even further. All those changes in the value of the CFA Franc against the FF and now the Euro, directly impacted the real exchange rate of Cameroon's local currency. Therefore, data from 1980 to 2016 will be analyzed to measure the response of Cameroon's trade balance to those fluctuations.

\section{Literature Review}

\section{A. Theories}

During the era of mercantilism, the focus was not on the exchange rate policy, considering the fact that the wealth of nations was believed to have depended solely on precious metals such as gold and silver. Even then, the management of the balance of trade was already one principal concern of policymakers advocating the suppression of imports by imposing excessive tariffs and the support of exports at the same time. However, arriving in the nineteenth century, as the emergence of the theory of comparative advantage was explained by David Ricardo (1817) that promoted international trade, economists lined up with standard trade theory. A country can take advantage of elastic demand instead of relying solely on its internal market. The Hecksher-Ohlin model for instance, pioneered by Hecksher (1919) and further developed by his student Ohlin (1933), describes how countries could benefit from international trade by exporting goods made with their cheap and abundant factors of production while importing goods that requires the countries' scarce factors to be made. The statement was simple: a fluctuation in the exchange rate affects both the value and volume of traded goods. Assuming that a real depreciation of a country's currency will automatically lead to a switch from consuming imported goods to consuming domestic ones, thus improving the trade balance.

The elasticities approach emerged during the interwar period and challenged the previous assumption by taking into account actual consumer behavior, meaning the responsiveness to price changes by domestic consumers of imported goods within the nation, and foreign consumers of that country's exports abroad. In fact, Bickerdike (1920), followed by Robinson (1947) and Metzler (1948) were the first to add a condition for the standard trade theory to work, known as the Bickerdike-Robinson-Metzler condition stating that the impact of a change in the exchange rate on the trade balance depends upon the imports and exports supply and demand elasticities, as well as the initial volume of trade, i.e., if the decline in value of domestic imports is greater than the decline in value of domestic exports, the trade 
balance will improve. Nevertheless, this first condition was not precise enough, so Lerner (1944) introduced another condition, named after Alfred Marshall (1923). The MLC implies that for a depreciation or devaluation of the exchange rate of a country's currency to improve the balance of trade, the sum of the absolute values of the price elasticities of demand for exports and imports must be greater than unity. If this condition is not met, the trade balance will either remain stable (if the sum equals to one) or worsen (if the sum is less than unity).

Another key contribution to the elasticities approach was brought by Magee (1973), right after the Bretton Woods system collapsed and the flexible exchange rate regime was adopted. Consumer behavior was not enough to predict the impact of a devaluation, but time should also be taken into consideration. Thus, the J-curve theory was born. In the short-run (passthrough period), demand is inelastic due to the slow reaction of the consumers and causes the trade balance to worsen. But as time elapses, they adapt to the new prices so that the volume and value of exports and imports will adjust in the long-run. If demand is elastic enough to meet the MLC's standards, the trade balance will improve and even surpass the level where it was before worsening.

Besides the standard trade theory and elasticities approach, other approaches were developed such as the Keynesian absorption approach and the monetary approach. According to those theories, microeconomic dynamics depicted by the economists of the elasticities approach were not enough to explain the relationship between the exchange rate and the balance of trade. For Meade (1951) and Alexander (1952), the main contributors of the absorption approach, a currency devaluation improves trade balance if the substitution toward domestic goods in response to the relative price change boosts output more than absorption. As a matter of fact, the expenditure on local output must exceed expenditure on imported goods for the balance of trade to change positively. Meanwhile, monetarists such as Miles (1979) emphasized the negative effect of the money supply on the trade balance. A devaluation can improve the trade balance only because such a decision will increase money demand. However, if policymakers decide to adjust the level of money supply to the new level of demand, it will undermine the positive effect caused by the devaluation on the balance trade. He concluded, therefore, that devaluations do not improve the trade balance, but only improve the balance of payments.

\section{B. Empirics}

To this day, the J-curve approach is the only method able to trace the effect of real exchange rate depreciation or devaluation on the trade balance over time. Over the years, many researchers were eager to verify the validity of the MLC and the J-curve phenomenon in the trade of various countries. Rose (1990) studied a number of developing countries using non-structured techniques and concluded that a depreciation rate is not strongly associated with a significant improvement in the trade balance. In the same way, Wilson (2001) found no evidence of a significant impact of the change in exchange rate on the real balance and nonexistence of J-curve phenomenon for Singapore and Malaysia for bilateral trade in merchandize goods with the U.S.A. and Japan using the partially reduced-form 
model. However, South Korean data were consistent with some J-curve effects with both the U.S.A. and Japan. Relying on the Indian experience, Ghosh (1990) argued that reliance on the exchange rate instrument alone as a means of improving the current deficit is unlikely to prove successful. All of these results happen because the relationship between the nominal and real exchange rates is unclear, and continuous devaluation of the nominal one creates expectations of future depreciation and thus exerts a negative influence on the current account.

Even if some empirical studies do not provide results validating the J-curve theory, many others do not have the same conclusion. It is the case for Shirvani and Wilbratte (1997) who tested the relationship between exchange rate and trade balance on bilateral trade between the U.S. and the G7 countries. In the short-run, the exchange rate was unresponsive but after a two-year pass-through, a significant change happened, leading to the obvious conclusion that devaluations do improve trade balance in the long-run. Stučka (2004) was even more precise in his conclusions after he searched for the existence of a J-curve in Croatia. According to that study, a percent permanent depreciation improved the equilibrium trade balance by between 0.94 percent and 1.3 percent. The new equilibrium was established after approximately 2.5 years. Studying the Brazilian case, Reis Gomes and Senne Paz (2005) also indicated that the MLC holds and J-curve phenomenon can be found after devaluation. For Brada, Kutan and Zhou (1993) the liberalization of the Chinese economy has made the exchange rate an effective indirect tool for regulating trade, since devaluation serves to improve the balance of trade in both the short and long runs. The same goes for NG, Har and Tan (2009) who noticed that in spite of the fact that no trace of the J-curve phenomenon in Malaysia could be found, results show that devaluation will improve the trade balance in the long-run. Using the cointegration technique to examine the short- and long-run relationships between the real Malaysian trade balance with the real exchange rate, Yussof (2007) concluded that a devaluation of the Ringgit will initially improve the trade balance. After that point, the trade balance starts to deteriorate, and then improves again, suggesting the existence of a delayed J-curve. However, Shabaz, Jalil and Islam (2012) found that a relationship between the real exchange rate and the trade balance exists in the long-run, but it was more likely to have worsened the deficit following a devaluation in Pakistan.

\section{Model Specification and Estimation Techniques}

\section{A. Data description}

The dataset analyzed in this study is sourced from the World Development Indicators published by the World Bank (2018). They are annual observations covering 1980 2016. Due to the lack of Cameroon's real effective exchange rate data from 1960 (the independence of Cameroon) to 1979, the observation is limited to 1980 2016. The real exchange rate is obtained by measuring the value of the local currency against a weighted average of several foreign currencies divided by a price deflator (or index of costs) with the index setting 2010 
$=100$. The domestic income is proxied by Cameroon's GDP ${ }^{1}$ and foreign income is proxied by the GDP of Cameroon's main export ${ }^{2}$ destinations (i.e., China, India, the Netherlands, France, and Spain).

Table 2. Descriptive statistics

\begin{tabular}{|l|c|c|c|c|}
\hline \multicolumn{1}{|c|}{ Statistics } & $\begin{array}{c}\text { GDP } \\
\text { Cameroon }\end{array}$ & $\begin{array}{c}\text { GDP Foreign } \\
\text { Trade Partners }\end{array}$ & $\begin{array}{c}\text { Real Exchange } \\
\text { Rate }\end{array}$ & $\begin{array}{c}\text { Net Trade } \\
\text { Balance }\end{array}$ \\
\hline Mean & $1.61 \mathrm{E}+10$ & $6.38 \mathrm{E}+10$ & 114.5700 & $-3.43 \mathrm{E}+08$ \\
\hline Median & $1.16 \mathrm{E}+10$ & $4.01 \mathrm{E}+10$ & 101.3779 & -30257921 \\
\hline Maximum & $3.49 \mathrm{E}+10$ & $1.79 \mathrm{E}+10$ & 165.8311 & $6.66 \mathrm{E}+08$ \\
\hline Minimum & $6.74 \mathrm{E}+00$ & $1.32 \mathrm{E}+10$ & 88.38160 & $-1.81 \mathrm{E}+09$ \\
\hline Std. Dev. & $8.61 \mathrm{E}+10$ & $5.43 \mathrm{E}+10$ & 22.70445 & $6.79 \mathrm{E}+10$ \\
\hline Skewness & 0.886702 & 1.020136 & 0.846194 & -0.824547 \\
\hline Kurtosis & 2.323877 & 2.600791 & 2.266424 & 2.376539 \\
\hline Jarque-Bera & 5.553246 & 6.663198 & 5.245228 & 4.791826 \\
\hline Probability & 0.062248 & 0.035736 & 0.072613 & 0.091089 \\
\hline Sum & $5.97 \mathrm{E}+11$ & $2.36 \mathrm{E}+11$ & $4,239.090$ & $-1.27 \mathrm{E}+10$ \\
\hline Sum Sq. Dev. & $2.67 \mathrm{E}+11$ & $1.06 \mathrm{E}+11$ & $18,557.72$ & $1.66 \mathrm{E}+19$ \\
\hline Observations & 37 & 37 & 37 & 37 \\
\hline
\end{tabular}

(Note) GDP for Cameroon is a proxy for domestic income, GDP foreign partners is a proxy for foreign income, the sum of Cameroon's main trade partners (i.e., China, India, the Netherlands, France, and Spain), real exchange rate is Cameroon's currency real exchange rate index for the base year $(2010=100)$.

(Source) Computation from time-series data using EViews.

${ }^{1}$ Gross Domestic Product (GDP) in current US dollars.

${ }^{2}$ Exports and imports of goods and services are based on the national accounts. 
Figure 1. Cameroon's net trade balance and real exchange rate

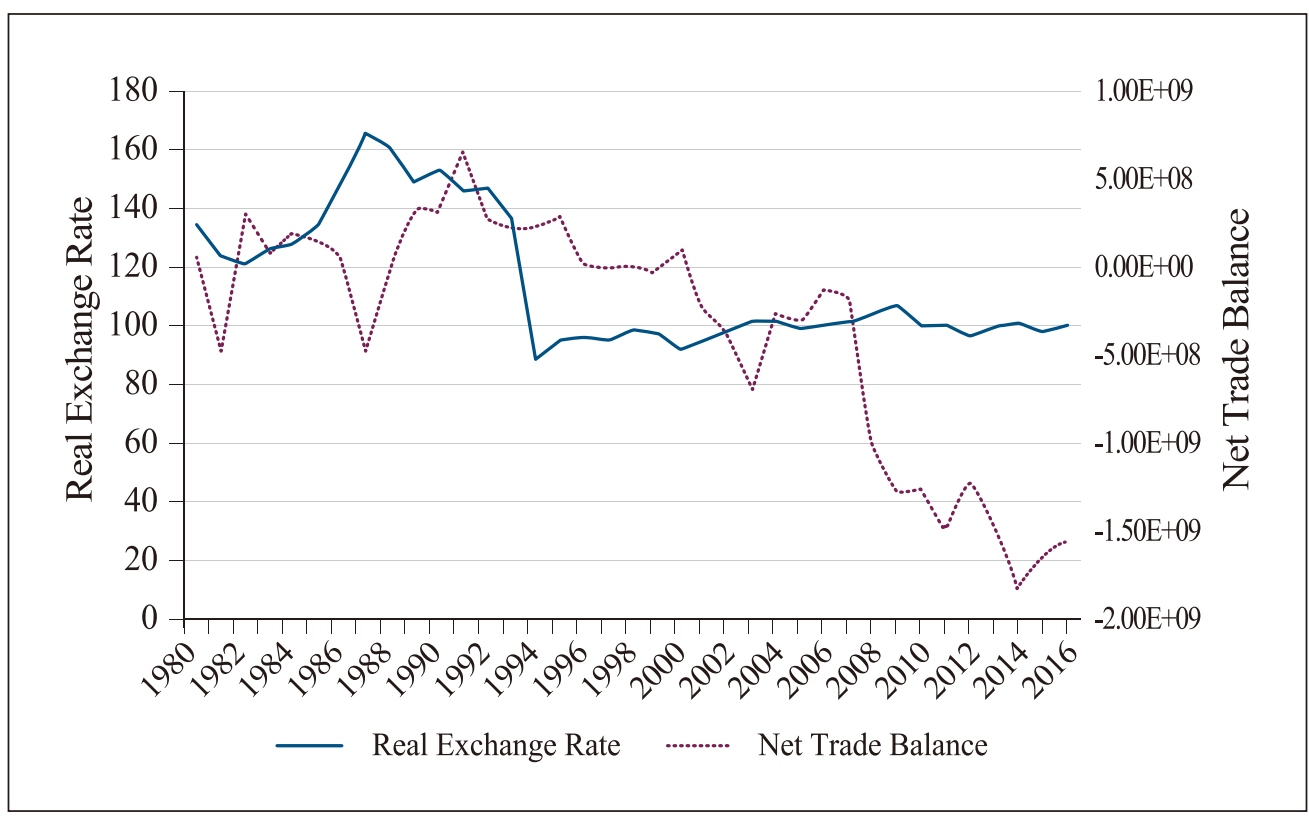

(Notes) The net trade balance in current US Dollars; the real exchange rate index for a base year of $2010=$ 100.

(Source) World Bank (2018), World Development Indicators.

As we observed in Figure 1, since the devaluation of the CFA Franc in 1994, the real effective exchange rate has remained quite stable, revolving around 100 (median $=101.3$; mean $=114.5)$. The trade balance, which had only been in a deficit twice (1981 and 1988) before the devaluation, worsened tremendously after 1996. Moreover, during 2000, the Euro was introduced in France, widening the gap between the French currency and the CFA Franc even further. The trade balance has not shown a surplus since then; in fact, the mean and the median values are negative. Nevertheless, the two graphs represented in Figure 1 seem to have opposite trends, meaning that the trade balance tends to improve through real exchange rate depreciations, and vice versa. Can those observations justify the potential existence of a negative correlation between the real exchange rate and the trade balance in the case of Cameroon? More than likely, the resulting figures are insufficient to draw such sweeping conclusions since we must prove the existence and nature of the relationship between the dependent and the independent variables first, and then determine the direction of the causality by further empirical testing. 


\section{B. Model specification}

In this section, we specify our theoretical regression model used to estimate the nature of the relationship between the real effective exchange rate and the trade balance in Cameroon. This country is a small open economy and a price taker, meaning that prices in the international market are settled by external institutions and Cameroon has no means of influencing the process. Therefore, exports depend mainly on foreign income of the main destinations of Cameroonian exports (i.e., China, India, the Netherlands, France, and Spain) and the real effective exchange rate of the CFA Franc. We must, however, note that China and India, the main contributors to Cameroon's export revenue are the most affected by such fluctuations, as Netherlands, France, and Spain use the Euro to which the CFA Franc is pegged. The same goes for the imports which depend on domestic income and Cameroon's real exchange rate, considering the fact that it influences the purchasing power of the local population. The functional forms of the demand for imports and the demand for exports may be written as follows:

$$
\begin{aligned}
& X_{t}=f\left(R E R_{t}, F I_{t}\right)+u_{i} \\
& M_{t}=f\left(R E R_{t}, D I_{t}\right)+v_{i}
\end{aligned}
$$

where $X_{t}=$ Cameroon's real exports of goods and services; $M_{t}=$ Cameroon's real imports of goods and services; $R E R_{t}=$ Cameroon's real exchange rate index (for base year $2010=$ $100) ; D I_{t}=$ Domestic income, proxied by Cameroon's GDP; $F I_{t}=$ Foreign income, proxied by main trading partners' GDP (i.e., China, India, Netherlands, France, and Spain as they constitute the lion's share of Cameroon's trade); $u_{i}, v_{i}$ denote disturbance terms.

The functional and explicit forms of the model are written as follows:

$$
\begin{gathered}
T B_{t}=f\left(R E R_{t}, D I_{t}, F I_{t}\right)+\varepsilon_{i} \\
T B_{t}=\alpha+\beta R E R_{t}+\gamma D I_{t}+\delta F I_{t}+\varepsilon_{i} \\
L n T B t=\alpha+\beta L n R E R_{t}+\gamma L n D I_{t}+\delta L n F I_{t}+\varepsilon_{i}
\end{gathered}
$$

where $T B_{t}=$ Cameroon's trade balance; $\varepsilon_{i}$ is the disturbance term.

The aim of the study is to observe whether or not real effective exchange rate $\left(R E R_{t}\right)$ depreciation remedies the trade deficit. Indeed, real exchange rate (RER) may have a significant impact on exports $\left(X_{t}\right)$ and imports $\left(M_{t}\right)$ which are used to evaluate the trade balance $\left(T B_{t}\right)$. Net exports, also referred to as the net trade balance, are a common way to evaluate the state of the trade balance: positive value $\left(X_{t}-M_{t}>0\right)$ is categorized as a trade surplus whereas negative net exports $\left(X_{t}-M_{t}<0\right)$ indicates a trade deficit. However, because Cameroon's net exports have several occurrences of negative values from 1980 to 2016 (Table 2), not allowing them 
to be written in logarithm form $(L n)$, the trade balance estimated in this study is the exports to imports ratio. This formula also describes the state of the trade balance, wherein the equilibrium value switch from zero to one, and values higher than one $\left(X_{t} M_{t}>1\right)$ indicate a trade surplus, while values smaller than unity $\left(X_{t} / M_{t}<1\right)$ indicate a trade deficit. The natural logarithm function of the trade balance $\left(\operatorname{Ln}\left(T B_{t}\right)=\operatorname{Ln}\left(X_{t} / M_{t}\right)=\operatorname{Ln}\left(X_{t}\right)-\operatorname{Ln}\left(M_{t}\right)^{3}\right)$ has the advantage of making the estimated coefficients directly interpretable as a percentage change and a measure of elasticity, allowing us to check whether or not the MLC is fulfilled as Onafowora (2003) pointed out. Moreover, it removes the need to explain the dependent variable (balance of trade) in real terms with the appropriate price index.

If the variables do not have unit roots, or in those cases where they do but are cointegrated, we shall estimate the equation in its original units or natural log as specified in Equation (5) above as mentioned by Studenmund (2006). However, using first differences like those specified in Equation (6) below is a better option if the variables have unit roots, even if they are not cointegrated:

$$
\Delta L n T B_{t}=\alpha+\beta \Delta L n R E R_{t}+\gamma \Delta L n D I_{t}+\delta \Delta L n F I_{t}+\varepsilon_{i}
$$

where $\Delta L n T B_{t}=L n T B_{t}-L n T B_{t-1}$. The expected signs of the coefficients according to economic theory are $\beta<0$, corresponding to the devaluation of the CFA Franc; $\gamma>0$ as the trade balance is supposed to improve after devaluation and have a positive effect on domestic income proxied by Cameroon's GDP, $\delta>0$ although exports' revenue will likely drop after the devaluation, it will likely rise again as the export volume goes up in the long-run due to the competitive prices of Cameroonian goods on the international market.

\section{Preliminary testing}

\section{Unit root tests}

Considering the time-series data itself, stationarity is a part of the Gauss-Markov conditions for unbiased efficient regression estimators ${ }^{4}$ in order to avoid spurious results. To be more specific, when applied to non-stationary data, regression analysis can inadequately lead to insignificant estimates that appear to be meaningful as stated by Granger and Newbold (1974), and supported by Hamilton (1994). Note that a stationary series is one whose basic statistical properties (i.e., its mean, expectancy, and variance) do not change over time. In contrast, a non-stationary series has one or more basic properties that do change over time. The Dickey-Fuller test is traditionally used to test for non-stationarity and in cases where a unit root is found, differencing the data is the easiest way to induce stationarity. Prior to running the unit root tests, autocorrelation of residuals must be avoided as it biases the standard errors (i.e., the $t$ values and $F$ tests) of estimates by selecting optimal lags. For

\footnotetext{
${ }^{3}$ If imports are greater than exports, then $\operatorname{Ln}\left(T B_{t}\right)=\operatorname{Ln}\left(X_{t} / M_{t}\right)=\operatorname{Ln}\left(X_{t}\right) \operatorname{Ln}\left(M_{t}\right)<0$, there is a trade deficit. ${ }^{4}$ The Akaike Information Criterion (AIC) gives the minimum values out of all the information criteria (Schwarz Information Criterion, Hannan Quinn Information Criterion), and is therefore our choice for conducting this study.
} 
The Impact of Real Exchange Rate Depreciation on Cameroon's Trade Balance: ls Devaluation a Remedy for Persistent Trade Deficits?

annual data, the number of lags ${ }^{5}$ is typically small, 1 or 2 is enough to guarantee non-residual autocorrelation.

Table 3. ADF and PP unit root tests

\begin{tabular}{|c|c|c|c|c|c|c|c|}
\hline \multirow[b]{2}{*}{ Variable } & \multirow[b]{2}{*}{ Trend } & \multicolumn{3}{|c|}{ ADF Test } & \multicolumn{3}{|c|}{ PHILIPS-PERRON Test } \\
\hline & & $t$-statistic & $\begin{array}{c}\text { Proba- } \\
\text { bility }\end{array}$ & Lag & Adj. $t$-stat & $\begin{array}{c}\text { Proba- } \\
\text { bility }\end{array}$ & Bdw \\
\hline \multicolumn{8}{|c|}{ Level } \\
\hline \multirow{2}{*}{$\begin{array}{l}\text { Domestic } \\
\text { Income }\end{array}$} & $\mathrm{NO}$ & -0.5980 & 0.8587 & 0 & -0.5673 & 0.8656 & 1 \\
\hline & YES & -1.8034 & 0.6822 & 0 & -1.8079 & 0.6800 & 1 \\
\hline \multirow{2}{*}{$\begin{array}{l}\text { Foreign } \\
\text { Income }\end{array}$} & $\mathrm{NO}$ & -0.2319 & 0.9250 & 1 & 0.4727 & 0.9833 & 2 \\
\hline & YES & -2.3834 & 0.3813 & 1 & -2.7832 & 0.2123 & 3 \\
\hline \multirow{2}{*}{$\begin{array}{l}\text { Real } \\
\text { Exchange }\end{array}$} & NO & -1.4777 & 0.5333 & 0 & -1.5379 & 0.5033 & 2 \\
\hline & YES & -1.8504 & 0.6589 & 0 & -1.9829 & 0.5906 & 2 \\
\hline \multirow{2}{*}{$\begin{array}{l}\text { Trade } \\
\text { Balance }\end{array}$} & $\mathrm{NO}$ & $-2.7212^{* * *}$ & 0.0803 & 0 & -2.5843 & 0.1054 & 1 \\
\hline & YES & $-3.7748 * *$ & 0.0298 & 0 & $-3.6910 * *$ & 0.0359 & 1 \\
\hline \multicolumn{8}{|c|}{ First Difference } \\
\hline \multirow{2}{*}{$\begin{array}{l}\text { Domestic } \\
\text { Income }\end{array}$} & NO & $-6.2821 *$ & 0.0000 & 0 & $-6.2859 *$ & 0.0000 & 2 \\
\hline & YES & $-6.2086^{*}$ & 0.0001 & 0 & $-6.2132 *$ & 0.0001 & 2 \\
\hline \multirow{2}{*}{$\begin{array}{l}\text { Foreign } \\
\text { Income }\end{array}$} & NO & $-4.5188^{*}$ & 0.0010 & 0 & $-4.4734^{*}$ & 0.0011 & 4 \\
\hline & YES & $-4.3651^{*}$ & 0.0074 & 0 & $-4.2983^{*}$ & 0.0087 & 4 \\
\hline \multirow{2}{*}{$\begin{array}{l}\text { Real } \\
\text { Exchange }\end{array}$} & NO & $-5.5962 *$ & 0.0000 & 0 & $-5.5960^{*}$ & 0.0000 & 1 \\
\hline & YES & $-5.5088^{*}$ & 0.0004 & 0 & $-5.5085^{*}$ & 0.0004 & 1 \\
\hline \multirow{2}{*}{$\begin{array}{l}\text { Trade } \\
\text { Balance }\end{array}$} & $\mathrm{NO}$ & $-9.5021^{*}$ & 0.0000 & 0 & $-10.782^{*}$ & 0.0000 & 7 \\
\hline & YES & $-9.6749^{*}$ & 0.0000 & 0 & $-12.354^{*}$ & 0.0000 & 9 \\
\hline
\end{tabular}

(Notes) $(*),(* *)$ and $(* * *)$ denote rejection of null hypothesis at $1 \%, 5 \%$, and $10 \%$ statistical significance, respectively. Bdw= Bandwidth (Newey-West, using Barlett kernel).

(Source) Computation from time-series data using EViews.

Except for the trade balance (LnTB), the augmented Dickey-Fuller (ADF) and PhillipsPerron (PP) unit root tests results covering 1980 2016, reported in Table 3, fail to reject the null hypothesis at each level, with or without a trend at $1 \%, 5 \%$, and $10 \%$ levels of

${ }^{5}$ What the Gauss-Markov theorem refers to as the Best Linear Unbiased Estimator (BLUE). 
significance. The variables domestic income $(L n D I)$, foreign income $(L n F I)$ and RER (LnRER) have unit roots and are not stationary at level. At first difference, the probability values of all the variables are less than $5 \%$ and the $t$-statistic values are greater than ADF and PP critical values, making the variables stationary at their first difference and are, therefore, integrated of order one I(1).

Without a trend, the ADF test results show that the $\boldsymbol{t}$-statistic is greater than the critical value of Mckinnon (1996) at a 10\% significance level for the trade balance (LnTB). However, the probability is greater than $5 \%$, making it impossible to reject the null hypothesis at the $10 \%$ significance level. When adding a trend, both the ADF and PP test results indicate that the trade balance $(\operatorname{LnTB})$ is stationary at a $5 \%$ significance level.

\section{Granger causality test}

In our model specification, the dependence of trade balance on other variables such as the $R E R$ is obvious, but it does not prove causality. Keeping in mind that the overall purpose of this study is to describe the relationship between the Cameroon RER the and trade balance, we thus need to have information concerning the direction of influence, i.e., to know which variable causes the other to move. For this purpose, the Granger causality test is useful when investigating causality between the variables of our time-series data. Developed by Granger (1969) and later popularized by Sims (1972) the technique aims to determine whether one time-series is useful in forecasting another. To be specific, a variable X "Granger causes" a variable $\mathrm{Y}$ if past values of $\mathrm{X}$ combined with past values of $\mathrm{Y}$ can better predict $\mathrm{Y}$ than past values of $\mathrm{Y}$ alone. In the present context, RER will "Granger-cause" trade balance if current values of trade balance are better predicted from lagged values of $R E R$ and trade balance data together than from lagged values of trade balance data alone.

There are a number of different tests for Granger causality, but our preference is to use the $F$-test. Assuming that the analyzed signals (variables) are covariance stationary, the relationship between them can be translated into a vector auto regression (VAR) model and written as follows:

$$
\begin{aligned}
& \operatorname{LnTB}_{t}=\sum_{k=1}^{n} a_{k} \operatorname{LnRER}_{t-k}+\sum_{k=1}^{n} b_{k} \operatorname{LnTB}_{t-k}+u_{1, k} \\
& \operatorname{LnRER}_{t}=\sum_{k=1}^{n} c_{k} \operatorname{LnTB}_{t-k}+\sum_{k=1}^{n} d_{k} \operatorname{LnRER}_{t-k}+u_{2, k}
\end{aligned}
$$

Since these variables are non-stationary at any level, as was shown in the previous section's results of the unit root tests, we need to convert them into stationary data by taking their first differences.

Then the basic steps for running the test are:

(1) State the null hypothesis: "RER does not Granger-cause a trade imbalance." 
(2) Select optimal lags.

(3) Find the $F$-value, by calculating $\sum_{k=1}^{n} a_{k}=0$, for all the values of $k$.

(4) The null hypothesis is rejected if the $F$-statistic is greater than the $F$-value.

Table 4: Granger causality test

\begin{tabular}{|l|c|c|}
\hline \multicolumn{1}{|c|}{ Null Hypothesis } & F-statistic & Probablility \\
\hline RER does not Granger-cause trade imbalance* & 5.25234 & 0.0041 \\
\hline Trade balance does not Granger-cause the RER* & 3.83090 & 0.0156 \\
\hline $\begin{array}{l}\text { Foreign income does not Granger-cause a trade } \\
\text { imbalance* }\end{array}$ & 3.08423 & 0.0346 \\
\hline Trade balance does not Granger-cause foreign income & 1.17885 & 0.3741 \\
\hline $\begin{array}{l}\text { Domestic income does not Granger-cause a trade } \\
\text { balance }\end{array}$ & 1.25853 & 0.3371 \\
\hline Trade balance does not Granger-cause domestic income & 2.01663 & 0.1251 \\
\hline
\end{tabular}

(Notes) $(*)$ denotes rejection of null hypothesis. Lag length $=7$ using Akaike Information Criterion (AIC). (Source) Computation from time-series data using EViews.

Granger causality tests results reported in Table 4 indicate that the RER and foreign income Granger-cause the trade balance of Cameroon, with the $p$-values below 0.05. However, results suggest independence between the variables domestic income and trade balance. Nevertheless, while using correlation to measure the strength and direction between those two variables, the significance of the coefficient of correlation $(-0.5926)$ proves the existence of a strong relationship, that justifies the selection of this variable in the explanation of the trade balance.

\section{Estimation methods}

As we have stated before, for a depreciation or devaluation of a country's currency to lead to an improvement in the current account balance, the summation of price elasticities of exports and imports must be greater than unity. The MLC must be met in order to achieve the result described by the J-curve. As the (ADF) and (PP) tests revealed the presence of both unit root and non-stationary data, the traditional approach consists in taking the first differences to convert the series into a stationary one. Unfortunately, correcting data this way throws away information that economic theory is normally able to provide in the form of equilibrium relationships between the variables when they are expressed in their original units. As a result, first differences should be used only after the residuals have been tested for cointegration. That is to say the degree of non-stationarity of the variables in an equation are 
matched in a way that makes the error term and residuals stationary. This process will rid the equation of any spurious results. Furthermore, applying the cointegration as well as the error correction mechanism (ECM) will also help us evaluate the long and short-run estimates and verify whether or not the MLC is met in the particular case of Cameroon.

To be more specific, if a set of time-series data are all I(1) they should not be estimated using ordinary regression analysis, because between them one or more equilibrium relationships (cointegrating vectors) may exist. We can both estimate those relationships using Johansen's technique. The Johansen cointegration test, named after Soren Johansen (1988), consists in detecting the number of cointegrating vectors between the dependent variable $(T B)$ and the independent variables using statistical values such as maximum eigen values or trace statistics. If a long-run equilibrium relationship exists between those variables then they are said to be cointegrated. Thus, the VAR is used to assess both the long- and short-run dynamics:

$$
\begin{aligned}
& \Delta \operatorname{LnTB}_{t}=\alpha+\sum_{i=0}^{m} \beta_{i} \Delta L n R E R_{t-i}+\sum_{j=0}^{n} \gamma_{j} \Delta L n D I_{t-j} \\
& +\sum_{k=0}^{p} \delta_{k} \Delta L n F I_{t-k}+\sum_{l=1}^{q} \mu_{l} \Delta L n T B_{t-l} \\
& -\varphi\left(\operatorname{LnTB}_{t-1}-\sigma_{0}-\sigma_{1} \operatorname{LnRER}_{t-1}-\sigma_{2} \operatorname{LnDI}_{t-1}-\sigma_{3} \operatorname{LnFI}_{t-1}\right) \\
& +\varepsilon_{t}
\end{aligned}
$$

where $\left[\alpha+\sum_{i=0}^{m} \beta_{i} \Delta L n R E R_{t-i}+\sum_{j=0}^{n} \gamma_{j} \Delta L n D I_{t-j}+\sum_{k=0}^{p} \delta_{k} \Delta L n F I_{t-k}+\sum_{l=1}^{q} \mu_{l} \Delta L n T B_{t-l}\right]$ is meant to represent the short-run dynamics of the relationship between the trade balance and the independent variables. The second part of this equation is written as $\left[-\varphi\left(\operatorname{LnTB}_{t-1}-\sigma_{0}-\sigma_{1} \operatorname{LnRER_{t-1}}-\sigma_{2} L n D I_{t-1}-\sigma_{3} L n F I_{t-1}\right)\right]$, represents cointegration, in other words the long-run information lost in the original estimation process. $\varphi$ is the adjustment speed (pass-through) between the short and long-run disequilibrium. It bears a negative sign due to the fact that $T B$ is supposed to deteriorate immediately after the currency depreciation or devaluation but eventually the dynamics will change, in the long-run, and improvements will thus become obvious. $\varepsilon_{t}$ is a white-noise term.

In cases where the variables are found to have one or more cointegrating vectors and a proven long-run stochastic trend, a suitable estimation technique of short-run dynamics is the ECM. Several methods of ECM are available. Among these are Engle and Granger twostep approach and the vector-based Johansen method. The Engle-Granger approach suffers from a number of weaknesses, some of them due to being restricted to only a single equation with a single variable explaining the dependent variable. Hence, the residuals obtained from the first regression stage cannot be verified, and at most one cointegrating relationship can be examined through this process. Johansen's procedure, also known as the vector VECM addresses those weaknesses and adjusts for both short-run changes in variables and deviations from equilibrium. 


\section{Discussion of the Findings}

\section{A. Empirical results for model estimation and interpretation}

\section{Long-Run relationship estimation: Johansen cointegration}

In order to determine the existence of one or more cointegrating vectors, the variables must be estimated using the Johansen cointegration tests. However, the variables must all be integrated of order one $\mathrm{I}(1)$, which is the case for RER, domestic income $(D I)$ and foreign income $(F I)$. Trade balance is trend stationary, meaning that when running the unit root tests without the trend, the variable has unit root at each level and is, therefore, considered integrated with order one I(1). Taking this into consideration, the unrestricted cointegration rank tests trace and max-eigen value were conducted using only an intercept but no trend. Moreover, the fact that too many lags may lead to the loss of degrees of freedom, statistically insignificant coefficients and multicollinearity, makes selecting optimal lags necessary in order to prevent such results. Thus, the optimal lag length selected using the Akaike information criterion (AIC) is where $p=3$. The results of both tests are displayed in tables 5 and 6 below.

Table 5. Johansen cointegration (trace)

\begin{tabular}{|l|c|c|c|c|}
\hline $\begin{array}{c}\text { Hypothesized number of } \\
\text { cointegrating equations }\end{array}$ & Eigen Value & Trace Statistic & $\begin{array}{c}\mathbf{0 . 0 5} \text { Critical } \\
\text { Value }\end{array}$ & $\begin{array}{c}\text { Probability } \\
\text { Value }\end{array}$ \\
\hline None* & 0.682269 & 68.35055 & 47.85613 & 0.0002 \\
\hline At most $1 *$ & 0.508969 & 30.51442 & 29.79707 & 0.0413 \\
\hline At most 2 & 0.181264 & 7.043254 & 15.49471 & 0.5726 \\
\hline At most 3 & 0.013349 & 0.443478 & 3.841466 & 0.5054 \\
\hline
\end{tabular}

(Note) Trace tests indicates two cointegrating equations at the 0.05 level. $(*)$ denotes rejection of null hypothesis at the 0.05 level. (**) Mackinnon-Haug-Michelis (1999) $p$-values. Number of lags $=3$ using Akaike information criterion (AIC).

(Source) Computation from time-series data using EViews. 
Table 6: Johansen cointegration (max-eigen value)

\begin{tabular}{|l|c|c|c|c|}
\hline $\begin{array}{c}\text { Hypothesized number of } \\
\text { cointegrating equations }\end{array}$ & Eigen Value & $\begin{array}{c}\text { Max-Eigen } \\
\text { Statistic }\end{array}$ & $\begin{array}{c}\mathbf{0 . 0 5} \text { Critical } \\
\text { Value }\end{array}$ & $\begin{array}{c}\text { Probability } \\
\text { Value }\end{array}$ \\
\hline None* & 0.682269 & 37.83614 & 27.58434 & 0.0017 \\
\hline At most $1 *$ & 0.508969 & 23.47116 & 21.13162 & 0.0230 \\
\hline At most 2 & 0.181264 & 6.599777 & 14.26460 & 0.5375 \\
\hline At most 3 & 0.013349 & 0.443478 & 3.841466 & 0.5054 \\
\hline
\end{tabular}

(Note) Trace tests indicates 2 cointegrating equations at the 0.05 level. $(*)$ denotes rejection of null hypothesis at the 0.05 level. (**) Mackinnon-Haug-Michelis (1999) $p$-values. Number of lags $=3$ using the Akaike information criterion.

(Source) Computation from time-series data using EViews.

Both trace and max-eigen value tests indicate the presence of two cointegrating equations or vectors at the 0.05 significance levels. This outcome translates into a cointegration rank being equal to $2>0$, thus revealing the existence of a long-run equilibrium relationship between our set of variables. Therefore, spurious regressions can be avoided. Here, the cointegration equation we chose to focus on is the one with the trade balance $(\operatorname{LnTB})$ as dependent variable, RER (LnRER), DI (LnDI) and FI (LnFI) as independent variables. The cointegrating equation is presented in Table 7 below.

Table 7. Normalized cointegrating equation

\begin{tabular}{|l|c|c|c|c|}
\hline \multicolumn{1}{|c|}{ Variable } & $\begin{array}{c}\text { Trade } \\
\text { Balance }\end{array}$ & $\begin{array}{c}\text { Real Exchange } \\
\text { Rate }\end{array}$ & $\begin{array}{c}\text { Domestic } \\
\text { Income }\end{array}$ & $\begin{array}{c}\text { Foreign } \\
\text { Income }\end{array}$ \\
\hline $\begin{array}{l}\text { Normalized } \\
\text { Coefficient }\end{array}$ & 1.00000 & 0.83213 & -0.51922 & 0.52559 \\
\hline Standard Error & & 0.24435 & 0.21655 & 0.15209 \\
\hline$t$-statistic & & $3.40547^{*}$ & $-2.39766^{*}$ & $3.45578^{*}$ \\
\hline $\begin{array}{l}\text { Adjustment } \\
\text { coefficient }\end{array}$ & -0.29377 & -0.41009 & -0.05351 & -0.23924 \\
\hline Standard Error & 0.23889 & 0.14632 & 0.22343 & 0.18021 \\
\hline
\end{tabular}

(Note) $(*)$ indicates that the t-statistic is statistically significant at the $1 \%$ level ( $t$-statistic magnitude $>2$ ). (Source) Computation from time-series data using Eviews 
In the long-run, the real effective exchange rate (LnRER) has a negative impact on the trade balance of Cameroon (LnTB) with a statistically significant estimated coefficient of 0.83 on average, ceteris paribus. That result is in line with the elasticities approach developed by Bickerdike (1920), Robinson (1947) and Metzler (1948) stating that if the decline in the value of domestic imports is greater than the decline in that of domestic exports, the trade balance will improve following the local currency devaluation. Furthermore, the expected sign predicted by economic theory pertaining to $D I(L n D I)$ is consistent with the rest of the results, as it has a positive impact on the trade balance. As expected, the devaluation led to a switch in spending from foreign to domestic goods causing a great decline in value of domestic imports. However, $F I(L n F I)$ had a negative impact on the trade balance, which was not consistent with the prediction. Magee (1973) have argued that contracts negotiated before the devaluation may be responsible for the deterioration of the trade balance in the short-run. This deterioration will certainly be corrected in the long-run if the MLC holds. The $t$-statistics that are greater than two in magnitude indicates statistically significant estimated coefficients at the $1 \%$ level.

\section{Short-run relationship estimation: Vector Error Correction Model}

If non-stationary but I(1) time-series are cointegrated, unrestricted VAR will not apply. The VECM is a special case of VAR which considers the cointegrating relations among the variables. The VECM will estimate both the short- and long-run dynamics of the series, as specified in Equation (9). In fact, the last period deviation from long-run equilibrium (the error) influences the short-run dynamics of the dependent variable. Thus, the coefficient of one or both of the cointegrating equations (CE), also referred to as ECT (error correction term) $\varphi$, directly estimates the speed at which a dependent variable returns to equilibrium after a change in other variables. If ECT is statistically significant with a negative sign, it implies that any shock happening in the short-run will be corrected in the long-run, proving the existence of a J-curve in the relationship between Cameroon's trade balance and the real effective exchange rate. The appropriate lag length for this analysis is 2 . 
Table 8. Estimated Vector Error Correction Model

\begin{tabular}{|l|c|c|c|}
\hline \multicolumn{1}{|c|}{ Variable } & Coefficient & Standard Error & t-statistic \\
\hline $\mathrm{CE}(1)$ & -0.811704 & 0.23304 & -3.48316 \\
\hline $\mathrm{CE}(2)$ & 0.473370 & 0.22135 & 2.13854 \\
\hline$\Delta L n T B_{t-1}$ & 0.036818 & 0.15585 & 0.23624 \\
\hline$\Delta L n T B_{t-2}$ & 0.110176 & 0.14126 & 0.77994 \\
\hline$\Delta L n R E R_{t-1}$ & -0.704330 & 0.30069 & -2.34239 \\
\hline$\Delta L n R E R_{t-2}$ & -0.110010 & 0.30765 & -0.35758 \\
\hline$\Delta L n D I_{t-1}$ & 0.016035 & 0.21234 & 0.07551 \\
\hline$\Delta L n D I_{t-2}$ & -0.085616 & 0.19427 & -0.44072 \\
\hline$\Delta L n F I_{t-1}$ & -0.063028 & 0.25732 & -0.24494 \\
\hline$\Delta L n F I_{t-2}$ & 0.193177 & 0.24023 & 0.80415 \\
\hline$C$ & -0.021832 & 0.02403 & -0.90849 \\
\hline
\end{tabular}

(Note) $R^{2}=0.4950 ;$ Adj. $R^{2}=0.2755 ;$ F-statistic $=2.2556 .(*)$ denotes significance at the $1 \%$ level. CE is cointegrating equation, also referred to as error correction term (ECT), $\varphi$; $\mathrm{C}$ is the constant; TB is trade balance; RER is real exchange rate; $D I$ is domestic income and FI is foreign income. denotes first difference and $L n$ denotes logarithmic form.

(Source) Computation from time-series data using EViews.

A long-run relationship with the RER, $D I$ and $F I$ exists with the trade balance $(T B)$, confirmed by the results displayed in Table 8 . In addition, to displaying the expected (negative) sign, one the first CE (1), is also referred to as the ECT and is statistically relevant. Only the first lag of the RER has a short-term causality with $T B$, as none of the other variables' first difference coefficients are statistically significant at the $1 \%$ level, at either lag one or lag two.

The existence of the J-curve phenomenon is confirmed, due to the fact that the initial worsening of the $T B$ will be corrected in the long-run. The coefficient -0.7043 measures the impact on Cameroon's $T B$ of a unit depreciation of the RER in the short-run. The comparison with the RER coefficient 0.8321 in the normalized cointegrating equation is seen in Table 7, which describes the long-run relationship between the variables. It is greater than the previous deterioration, thus validating the existence of a J-curve phenomenon in the case of Cameroon. The estimated coefficient of the ECT is -0.8117 , meaning that the previous period's deviation from long-run equilibrium is corrected in the current period at an adjustment speed of $81.17 \%$. 


\section{B. Testing estimated model reliability and stability}

\section{Model diagnostics for regression}

To ensure whether the VECM is correctly specified or not, a set of diagnostics assessments, such as tests for normality, serial correlation, and heteroskedasticity need to be performed. In fact, after fitting a regression model, it was necessary to determine whether all the important model assumptions are valid. During the empirical analysis, Johansen cointegration and VECM methods were used to obtain estimates of regression coefficients from the collected data. However, in order for regression estimators to be considered the best available, a set of fairly basics assumptions had to be met as noted by Studenmund (2006). Needless to say, any violation of the said assumptions can result in invalid conclusions. Therefore, performing appropriate model diagnostics is crucial. The classical assumptions state that the regression model is linear with an error term that has a mean of zero, and that it is uncorrelated with the explanatory variables and other observations of the error term (no serial correlation), has a constant variance (no heteroskedasticity), and is normally distributed (normality). The Breusch-Godfrey serial correlation LM (Lagrange multiplier) test developed by Breusch (1978) and improved by Godfrey (1978) is a test for autocorrelation in the error term. This test is more general than the Durbin-Watson statistic, and is more powerful statistically. The results yielded no serial correlation in the estimated model $(\operatorname{LM}[1]=19.51$; probability $=0.2429$ ). Likewise, the white heteroskedasticity test confirmed that there was no proof of heteroskedasticity in the model (Chi-squared $=200.3639$; probability $=0.4795)$, and the Jarque-Bera test for normality (joint $=6.8379$; probability $=0.5542$ ) displayed probability values higher than the 0.05 significance level, showing that the error term is normally distributed. Diagnostic tests conducted for normality, autocorrelation and heteroskedasticity showed that, overall, the model was stable.

\section{Impulse response and residuals analysis}

In order to confirm that the model is dynamically stable, and also to quantify the $T B$ response to an unexpected shock on the RER several periods later, residuals were analyzed and the results illustrated by the impulse response function (IRF). An impulse response is the reaction of any dynamic system in reaction to some external change. As a time-series model can be written as an indefinitely lagged moving average model, equilibrium values from the original vector autoregressive (VAR) results can be used to evaluate the impact of shocks as stated by Brandt and Williams (2006). In this case, the residuals from the estimated VECM constitutes a shock or random external change to the equation and will be used to analyze the IRF in order to assess how changes in one variable affect other ones over time. Thus, the IRF can be described as the effect on variable $i$ of a unit innovation in the $n^{\text {th }}$ variable that has occurred $k$ periods ago. Major distortions in the impulse responses are expected if important variables, assumed to be in the innovations, are omitted. Figure 2 shows the response of the $T B$ to a change in the RER. 
Figure 2. Response of trade balance to a shock in the real exchange rate

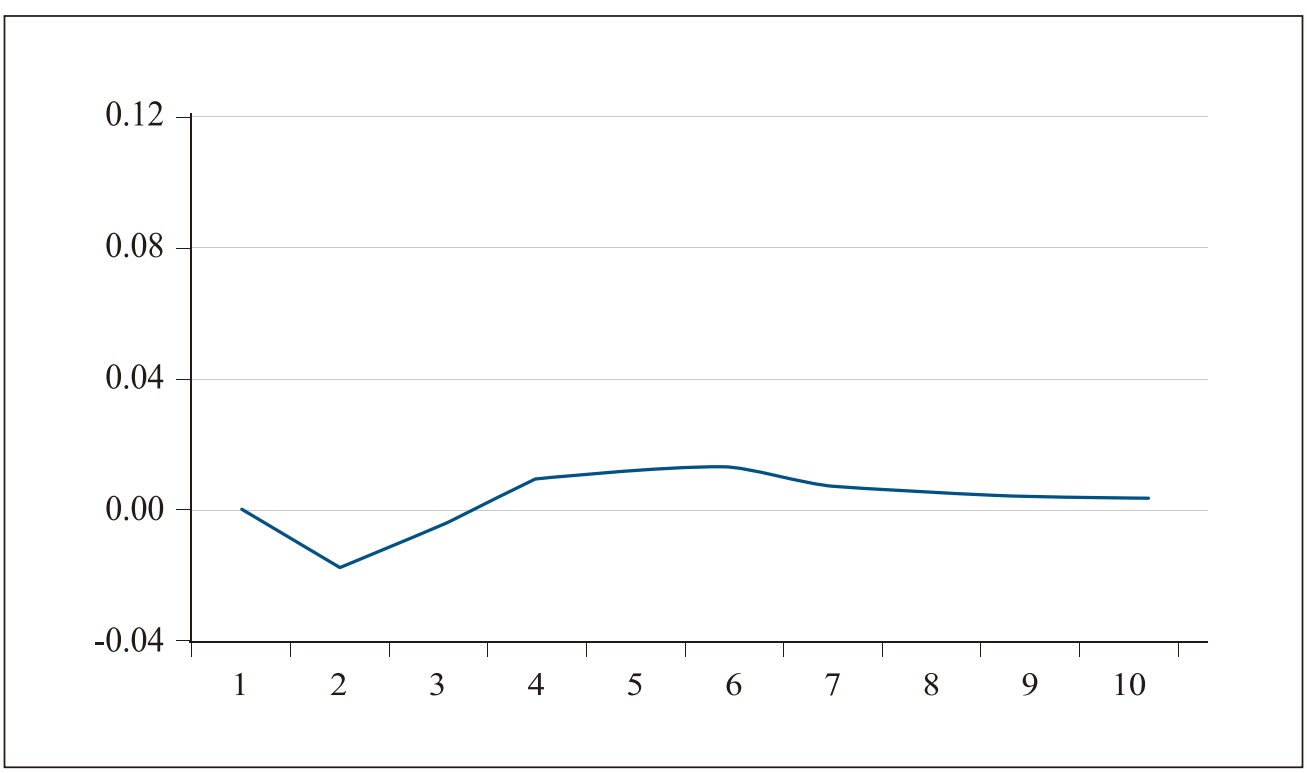

(Notes) Response of trade balance $(L n T B)$ to real exchange rate (LnRER), Cholesky one standard deviation innovations (using VECM).

(Source) Computation from time-series data using EViews.

According to Lütkepohl (2005), it is customary to scale the impulse responses by the standard deviation. Thus, in Figure 2, innovations of one standard deviation rather than unit shocks have been considered in order to cope with the different scales of the variables. A onestandard deviation shock to the RER causes the $T B$ to decrease for about one period. Then it returns to its initial value three and one-half periods after the shock occurred, eventually going beyond and staying on the surplus side ${ }^{6}$ until the $6^{\text {th }}$ period, before returning to equilibrium. These observations are consistent with the J-curve theory. ${ }^{7}$

${ }^{6}$ If $\operatorname{Ln}\left(T B_{t}\right)>0$, then $T B_{t}>1$, there is a trade surplus. However, if $\operatorname{Ln}\left(T B_{t}\right)<0$, then $0<T B_{t}<1$, there is a trade deficit. ${ }^{7}$ Magee (1973) argued that, inelastic demand causes the trade balance to worsens in the short-run, but consumers eventually adapt to the new prices so that the volumes and values of exports and imports will adjust in the long-run. 


\section{Figure 3. Response of trade balance to a shock on trade balance,} real exchange rate, domestic income and foreign income.

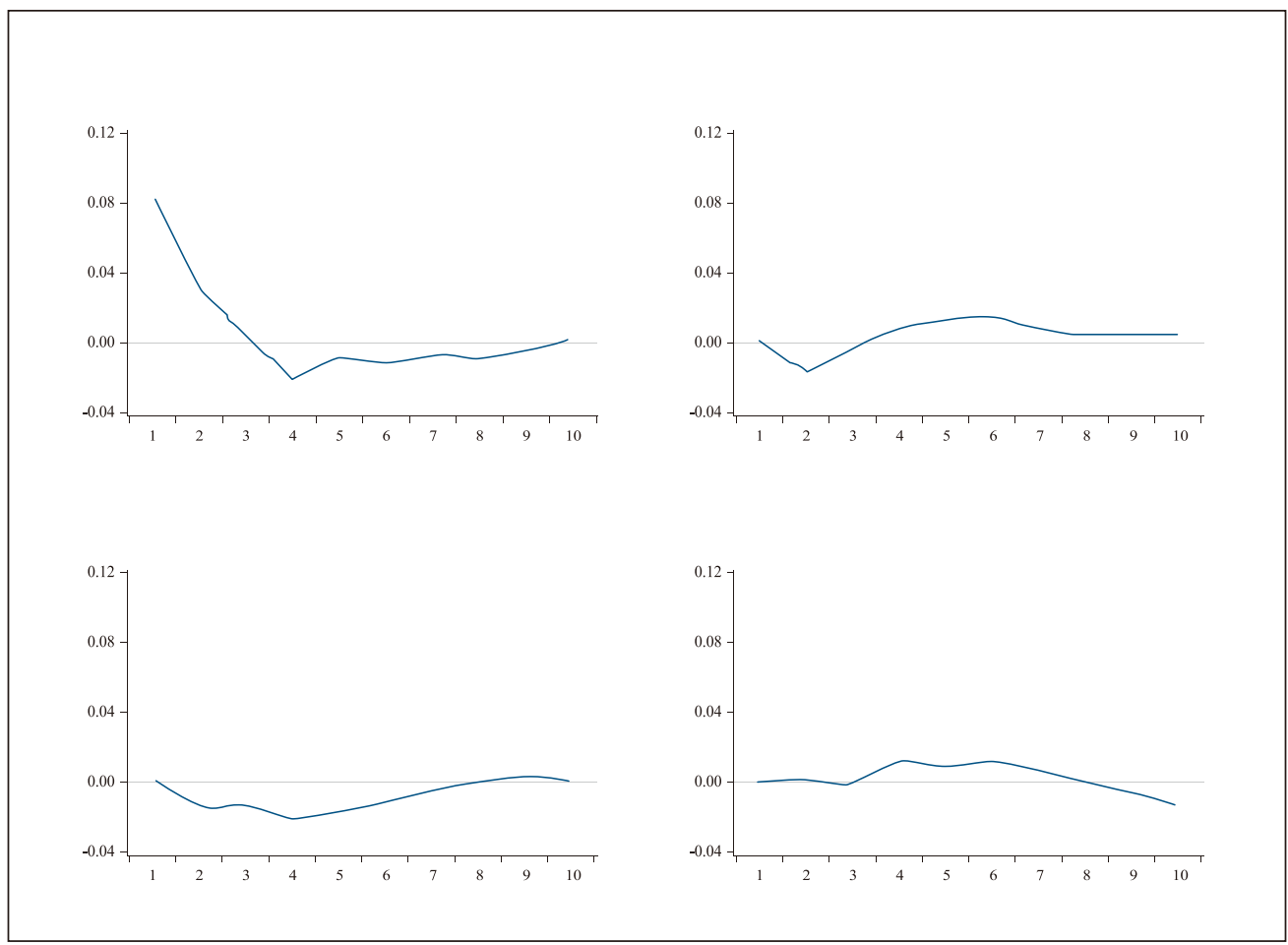

(Notes) Response of trade balance to trade balance $(L n T B)$, real exchange rate $(L n R E R)$, domestic income $(L n D I)$ and foreign income $(L n F I)$. Cholesky one standard deviation innovations (using VECM).

(Source) Computation from time-series data using EViews.

Besides, Lütkepohl (2005) argued that a VAR is stable when the IRFs converge to zero as the time period grows longer. The graphs in Figure 3 indicate that the estimated model is dynamically stable as the IRF of $T B$ (the dependent variable) converge to zero after some periods following the initial shock affecting all the independent variables.

\section{Conclusion, Suggestions, and Recommendations}

The sum of the elasticities of the demand for Cameroon's imports and exports (or the elasticity of the TB) in response to the devaluation of the RER of the local currency (the CFA Franc), represented in the model by the coefficient of the RER variable (LnRER), is not greater than unity, and thus does not satisfy the MLC. The reason must be the low level of available domestic substitutes for imported goods first, and then the fact that Cameroon mainly exports raw materials and low-value-added products abroad because the industrial 
revolution is yet to arrive in Cameroon. Consequently, Cameroon does not have much influence on the setting of the prices of exported goods as this country is solely a pricetaker. Nevertheless, according to the results of this study, it is safe to conclude that there exists a negative correlation between the TB and the RER. The deterioration of the TB in the short-run will be corrected in the long-run, thus proving the existence of a J-curve effect in this case. In Cameroon, the devaluation of the local currency appears as a remedy for trade deficits.

However, if the devaluation of the RER has a positive effect on the TB, the question is, "to what extent?" It is difficult not to notice that in spite of the TB being quite sensitive to RER fluctuations, the TB was more often on the surplus side than in deficit before the devaluation of the CFA Franc in 1994 (Figure 1). The later observation is more consistent with the MLC that states that when the sum of elasticities of demand for imports and exports is less than unity, the TB deteriorates in the long-run. The deterioration has been deeper since 2000, when the Euro was implemented, causing Cameroon's local currency to depreciate tremendously against some of its main partners' new currency. Taking this into consideration and although evidence of a J-shaped TB curve is found in this study, a suggestion for further research might be to investigate the reasons why the deficit is persistent in Cameroon despite several occurrences of past currency depreciations.

In terms of recommendations, Cameroon policymakers are obviously limited in their decisions due to the fact that the country shares its monetary policy with CEMAC members and France. Moreover, the results may indicate a positive impact on the TB following devaluation. However, policymakers should be careful not to undermine the improvement by adjusting the level of the money supply to the new level of money demand as emphasized by the monetarist Miles (1979). This mistake may be the reason why past devaluations of the CFA Franc did not appear to be the proper response to a persistent trade deficit. Furthermore, Cameroon is not yet an industrialized country and relies heavily on imports rather than production of manufactured goods. On the one hand, if import substitutes are not available to the local population, the switch in consumption predicted by the standard trade theory will not happen even after devaluation to lower importation expenses. On the other hand, industrialization will diversify the exports in order to improve revenues. This fact is important, especially when some studies conclude that when devaluation takes place under an existing trade deficit, as will likely be the case with Cameroon, contractionary effects due to the devaluation are to be expected, according to Krugman and Taylor (1978).

Received 29 January 2019, Accepted 13 February 2019 


\section{References}

Alexander, Sidney S. "Effects of a Devaluation on a Trade Balance." IMF Staff Papers 2.2 (1952): 263-278.

Bickerdike, Charles F. "The instability of foreign exchanges.” The Economics Journal 30.117 (1920): 118-122.

Brada, Josef C., Ali Kutan, and Su Zhou. "China's exchange rate and the balance of trade." Economics of Planning 26.3 (1993): 229-242. Doi: 10.1007/BF01265668.

Breusch, Trevor. "Testing for autocorrelation in dynamic linear models." Australian Economic Papers 17.31 (1978): 334-55. Doi:10.1111/j.1467-8454.1978.tb00635.x.

Brandt, Patrick T., and John T. Williams. Multiple Time Series Models. SAGE Publications (2006).

Devarajan, Shantayanan and Jaime de Melo. “Adjustment with a Fixed Exchange Rate: Cameroon, Cote d'Ivoire, and Senegal.” World Bank Economic Review 1.3 (1987): 447-487. Doi: 10.1093/wber/1.3.447.

Dhakir, Abbas A., Fuadah Johari and Mohammad Haji A. "The Effect of Exchange Rate Movements on Trade Balance: A Chronological Theoretical Review" Economics Research International (2014): Vol. 2014, Article ID 893170. Doi: 10.1155/2014/893170.

Ghosh, Jayati. "Exchange Rates and Trade Balance: Some Aspects of Recent Indian Experience." Economic and Political Weekly 25.9 (1990): 441-445.

Godfrey, Leslie. "Testing against general autoregressive and moving average error models when the regressors include lagged dependent variables." Econometrica 46.6(1978): 12931302. Doi: $10.2307 / 1913829$.

Granger, Clive. "Investigating Causal Relations by Econometric Models and Cross-spectral Methods" Econometrica 37.3 (1969): 424-438. Doi: 10.2307/1912791.

Granger, Clive and Paul Newbold. "Spurious regressions in econometrics." Journal of Econometrics 2.2 (1974): 111-120. Doi: 10.1016/0304-4076(74)90034-7.

Hamilton, James. Time Series Analysis. Princeton: Princeton University Press (1994).

Heckscher, Eli. "The Effect of Foreign Trade on the Distribution of Income." Ekonomisk 
Tidskrift (1919): 497-512.

Johansen, Soren. "Statistical analysis of cointegration vectors." Journal of Economics and Control 12 (1988): 231-254.

Johansen, Soren and Katarina Juselius, "Maximum likelihood estimation and inference on cointegration with applications to the demand of money." Oxford Bulletin of Economics and Statistics 52 (1990): 169-210. Doi: 10.1111/j.1468-0084.1990.mp52002003.x.

Krugman Paul and Lance Taylor. "Contractionary effects of devaluation." Journal of International Economics 8.3 (1978): 445-456.

Lerner, Abba P. The Economics of Control: Principles of Welfare Economics. New York: The Macmillan Company (1944).

Lütkepohl, Helmut. New Introduction to Multiple Time Series Analysis. Berlin: Springer (2005).

Magee, Stephen P. "Currency Contracts, Pass-through, and Devaluation." Brookings Papers on Economic Activity 1973. 1 (1973): 303-325. Doi: 10.2307/2534091.

Marshall, Alfred. Money, Credit and Commerce. London: Macmillan (1923).

Metzler, Lloyd A. "The Theory of International Trade." A Survey of Contemporary Economics, ed. Howard S. Ellis (Philadelphia: Blakiston,1948): 252.

Miles, Marc A. "The Effects of Devaluation on the Trade Balance and the Balance of Payments: Some New Results.” Journal of Political Economy 87 (1979): 600-620.

NG, Yueng-Ling, Wai-Mun Har, and Geoi-Mei Tan. "Real Exchange Rate and Trade Balance Relationship: An Empirical Study on Malaysia." International Journal of Business and Management 3.8 (2008): 130-137. Doi: 10.5539/ijbm.v3n8p130.

Ohlin, Bertil G. Interregional and international trade. Cambridge: Harvard University Press (1933).

Onafowora, Olugbenga. "Exchange Rate and Trade Balance in East Asia: Is There a J-Curve?" Economics Bulletin 5.18 (2003): 1-13.

Reis Gomes, Fabio A. and Lourenco Senne Paz. "Can real exchange rate devaluation improve the trade balance? The 1990-1998 Brazilian case." Applied Economics Letters 12.9 (2005): 525-528. Doi: 10.1080/13504850500076908. 
Ricardo, David. On the Principles of Political Economy and Taxation. London: John Murray (1817).

Robinson, Joan. Essays in the Theory of Employment. Oxford: Basil Blackwell, 1947.

Rose, Andrew K. "Exchange rates and the trade balance: Some evidence from developing countries" Economics Letters 34.3 (1990): 271-275. Doi: 10.1016/0165-1765(90)90130-S.

Samuelson, Paul A. "International Factor-Price Equalization Once Again.” Economic Journal 59 (1949): 181-197.

Shabaz, Muhammad, Abdul Jalil and Faradul Islam. "Real Exchange Rate Changes and the Trade Balance: The Evidence from Pakistan.” The International Trade Journal 26.2 (2012): 139-153. Doi: 10.1080/08853908.2012.657588.

Shirvani, Hassan and Barry Wilbratte. "The relationship between the real exchange rate and the trade balance: An empirical reassessment.” International Economic Journal 11.1 (1997): $39-50$.

Sims, Christopher A. "Money, Income, and Causality." The American Economic Review 62.4 (1972): 540-552.

Stucka, Tihomir P. "The effect of exchange rate change on the trade balance in Croatia." IMF Working papers (2004): No. 04/65.

Studenmund, A. H. Using Econometrics: A practical Guide, $5^{\text {th }}$ Edition. Edinburgh: Pearson Education, Inc. (2006).

Wilson, Peter. "Exchange rates and the trade balance for dynamic Asian economies-Does the J-Curve exist for Singapore, Malaysia, and Korea?" Open Economies Review 12.4 (2001): 389-413. Doi: 10.1023/A:1017982901034.

Yussof, Mohammed B. "The Malaysian Real Trade Balance and the Real Exchange Rate." International Review of Applied Economics 21.5 (2007): 655-667. Doi: 10.1080/02692170701474686.

World Bank (2018). "World Development Indicators.” https://data.worldbank.org/ « Histoire du Franc CFA », BCAO (Banque Centrale des États de l'Afrique de l'Ouest), last update in 2018. https://www.bceao.int/fr/content/histoire-du-franc-cfa. 